\title{
Goliński, Mateusz. Późnośredniowieczne spisy wywołanych z Jawora i Świdnicy. Kraków: Księgarnia Akademicka, 2020, LXXVJJ + 258 ss.
}

Keywords: municipal cort books, proscription, Silesia, Świdnica, Jawor, Middle Ages, penal law

Słowa kluczowe: księgi miejskie, proskrypcja, Śląsk, Świdnica, Jawor, średniowiecze, prawo karne

Miejskie księgi proskrypcji to zarazem rezerwuary wartościowej wiedzy o dawnym prawie, przestępczości i obyczaju, jak też niewdzięczny przedmiot edycji. Tym bardziej cieszyć się należy, że dwa niewydane dotąd późnośredniowieczne źródła tego typu ze Śląska zostały niedawno udostępnione zainteresowanym w postaci nowoczesnej edycji przez wytrawnego znawcę średniowiecznych śląskich źródeł proweniencji miejskiej, prof. Mateusza Golińskiego. Przedmiotem najnowszej edycji przygotowanej przez wrocławskiego badacza, wydanej przez krakowskie wydawnictwo Księgarnia Akademicka, są rękopisy przechowywane w dwóch różnych oddziałach Archiwum Państwowego we Wrocławiu (legnickim i wrocławskim): jaworski rejestr proskrybowanych z lat 1381-1450 oraz świdnicka księga proskrypcji i ułaskawień z lat 1380-1485. Źródła te przed wydaniem ich drukiem nie były historykom nieznane, lecz niewielki stopień ich wykorzystania w dotychczasowych badaniach jest niewspółmierny do ich znaczącej wartości poznawczej.

Recenzowana pozycja to de facto dwie książki w jednej okładce, gdyż omówieniu każdego z dwóch źródeł wydawca poświęcił osobny fragment wstępu redakcyjnego, a edycje obydwu - wykonane według tej samej, przedstawionej na s. LXXIII-LXXIV wstępu instrukcji - opatrzone zostały odrębnymi indeksami (miejsc i osób oraz rzeczowymi). Koncept taki jest ze wszech miar słuszny i ułatwia korzystanie z edycji, gdyż obszary jurysdykcji Jawora i Świdnicy stanowiły w dużej mierze osobne, nieczęsto zazębiające się mikroświaty, w związku z czym opatrzenie edycji wspólnymi indeksami (szczególnie osób i miejsc) przyniosłoby więcej szkody niż pożytku. Wstęp wydawniczy zawiera nie tylko podstawowe informacje o rękopisach $\mathrm{i}$ ich dotychczasowym wykorzy- 
staniu w badaniach historycznych, lecz także dość szczegółowe i rozległe partie przedstawiające i komentujące ich treść, $w$ tym m.in. opatrzone tabelami i rycinami ustępy dotyczące miejsc pochodzenia sprawców i ofiar, uwagi o rodzajach zapisek umieszczanych w obydwu księgach i społeczno-zawodowej kondycji osób występujących w rejestrach ${ }^{1}$, a w przypadku księgi świdnickiej także o niemczyźnie tych zapisek. Bardzo pożyteczne są także zestawienia deliktów, narzędzi zbrodni i pojawiających się w księgach terminów służących do ich określenia. Istotne są spostrzeżenia wydawcy dotyczące zasięgów jurysdykcji karnej miejskich sądów oraz przypadków jej niepokrywania się z zasięgami weichbildów, a także zjawiska kurczenia się z czasem stref, w których w praktyce uznawano kompetencje sądów jaworskiego i świdnickiego in maioribus. To ostatnie zjawisko wydawca tłumaczy - najpewniej słusznie - narastającą z czasem (szczególnie w XV w.) asertywnością okolicznego rycerstwa oraz nabywaniem przez kolejnych posiadaczy wsi praw do sądownictwa wyższego w swych dobrach (zob. wstęp, s. XI-XII, XIX-XX, LIX). Słusznie też M. Goliński wskazuje (s. LXIII) na locus delicti (drogę książęcą) jako na okoliczność thumaczącą proskrybowanie przez sąd wiejski osób szlachetnego stanu.

O ile jaworski rejestr proskrypcji (na który składają się dwie tematycznie jednolite partie bardziej wielowątkowego rękopisu) zawiera przede wszystkim zapiski dotyczące wywołania konkretnych osób, o tyle treść rękopisu świdnickiego - choć też w całości prawnokarna - jest bardziej zróżnicowana. Oprócz bardzo interesujących zapisek dotyczących relacji z księżną wdową Agnieszką oraz rycerstwem i klasztorem krzeszowskim (zob. np. zapiski nr 4-8, 47, 102, 120, 152, 193), a także stosunków panujących wśród elity miejskiej (np. nr 190, 505, 508, 514), znajdzie tam czytelnik m.in. noty świadczące o gromadzeniu w Świdnicy danych o sprawcach przestępstw kryminalnych pochodzących z innych ośrodków (miast i zamków, w tym Rogowca, Grodna, Sobótki, Kamiennej Góry, Trutnova - zob. np. zapiski nr 82-84, 86, 150, 182, 184, 188, 212) oraz liczne ugody kompozycyjne i przysięgi pokoju, w tym takie, w których stroną było miasto (nr 104) bądź wspólnie miasto i dominium zamku Rogowiec (nr 309); w dalszej partii rękopisu zapiski dotyczące zaprzysiężenia pokoju wręcz przeważają nad notującymi proskrypcje (np. nr 318-385 to niemal same zapisy dotyczące zniesienia proskrypcji po zadośćuczynieniu i przysiąg pokoju). Nie brakuje w księdze świdnickiej partii pozwalających na wgląd w obyczajowość i pojęcia epoki. Warto w tym kontekście wymienić m.in. zapiskę nr 132, w której powód z Wilkowa domagał się nie tylko ukarania winnego zabójstwa jego konia, ale także wpisu swojej skargi do księgi miejskiej, czy też zapiskę nr 572 dotyczącą niejakiej Katarzyny, wdowy po Jakubie Clossie, uznanej za osobę, która przyczyniła się do jego samobójstwa.

W obydwu księgach znajdują się zapiski dokumentujące sprawy, w które oprócz sądu miejskiego oraz landwójta, sołtysów (w zapisce nr 218 rejestru jaworskiego występuje też zastępca sołtysa: scultetus substitutus) i ławników innych miejscowości (w charakterze delatorów) zaangażowane były też inne instancje, przede wszystkim sąd dworski wraz z ławnikami ziemskimi (zob. np. zapiski nr 260, 262, 278, 290 w rejestrze jaworskim

${ }^{1}$ Spektrum statusów społecznych i zawodowych - zarówno miejskich, jak i wiejskich - jest w obu księgach naprawdę spore (obejmuje ono m.in. przedstawicieli czeladzi sołtysiej, por. zapiski nr 67, 105 w rejestrze jaworskim: sołtysi owczarz i woźnica), przy czym słusznie wydawca zwraca uwagę (s. XXXV, XXXVII) na nadreprezentację służących i pasterzy, podając prawdopodobną przyczynę takiego stanu rzeczy. 
oraz nr 95 i 109 w księdze świdnickiej)². Księga świdnicka przynosi także interesujące informacje o liczbie ławników, którzy wraz z sołtysem i landwójtem wnosili o wywołanie oskarżonych (od 1 do 4, zob. zapiski nr 201, 232, 233, 236, 269). W obu źródłach wydanych i opracowanych przez M. Golińskiego notowano też czasem - zapewne wtedy, gdy miało to znaczenie prawnoformalne - pewne szczegóły dotyczące jurysdykcji miejskiej i ziemskiej (rejestr jaworski, nr 238: wzmianka o proskrypcji ziemskiej; księga świdnicka, nr 410: zaznaczenie, że przestępstwo miało miejsce in statrecht; tamże, nr 444: adnotacja o proskrypcji ziemskiej tak daleko, jak sięga wyższy sąd miasta). Z perspektywy studiów nad historią prawa i dziejami piśmienności interesujące mogą okazać się także zapiski notujące przestępstwa przeciw dokumentom (rejestr jaworski, nr 141) oraz groźby przemocy wyrażone na piśmie (drewbriffe: księga świdnicka, nr 507 i 553).

Zastosowana przez wydawcę autorska instrukcja wydawnicza pozwoliła na udostępnienie czytelnikom bliskiej oryginałowi transkrypcji wraz z niezbędnymi informacjami o charakterze źródłoznawczym i objaśnieniami merytorycznymi. O sumienności wydawcy świadczy brak ewidentnie błędnych odczytów; co najwyżej znajdzie czytelnik miejsca, w których brakuje spodziewanych uzupełnień (w księdze świdnickiej: zapiska $\mathrm{nr} 40$ brayator zamiast bra[s]yator, tak też w indeksie; zapiska nr 139: von der sachin wege zamiast ...wege[n]). Przypisy rzeczowe są zwięzłe, a przy tym umieszczone w najpotrzebniejszych miejscach; zawierają informacje kluczowe dla zrozumienia zapisek (np. przyp. 7 na s. 19, do zapiski nr 211 rejestru jaworskiego, z celną interpretacją zapisu Rogost jako błędnie rozwiniętego z suspensji Rogosen, czy też objaśnienie zapisu Grissow w zapiskach nr 38 i 44 księgi świdnickiej jako Krzyżowej, nie Krzeszowa). Jedynym trudnym do wythumaczenia elementem instrukcji wydawniczej jest pominięcie w numeracji zapisek zawierających datacje i wyliczenia rajców miejskich - w końcu zostały one zindeksowane jak wszystkie inne; o ileż prościej byłoby zatem ponumerować je zamiast potem tworzyć do nich odsyłacze w indeksie typu „po 222”. Pewnym mankamentem zastosowanej metody edycji, ogólnie wzorowej, jest niezałączenie do książki fotokopii oryginałów źródeł. Sprawia to, że w przypadku błędnych zapisów nieoznaczonych przez wydawcę wykrzyknikiem czytelnik nie wie, czy ma do czynienia z niepoprawnym odczytem, nieoznaczonym błędem czy tylko uchybieniem zecerskim. Warto jednak zaznaczyć, że w żadnym z takich miejsc, jakie udało się dostrzec (np. zapiski nr 200, 203, 222/223, 231, 236, 240, 268 w rejestrze jaworskim, nr 2 w świdnickim), ewentualne niejasności interpretacyjne nie rzutowały na możliwość właściwego odczytania i zrozumienia treści poszczególnych zapisek przez czytelnika znającego podstawy gramatyki łacińskiej.

Edycje obydwu ksiąg zostały opatrzone indeksami osobowo-miejscowymi i rzeczowymi. Szczególnie indeksy rzeczowe - ściślej rzecz ujmując, „rzeczy i pojęć” - stanowiły z pewnością spore wyzwanie, m.in. ze względu na konieczność zindeksowania zapisek łacińskich i średniowysokoniemieckich. Wydawca wykonał to zadanie wzorowo, uwzględniając szerokie spektrum haseł rzeczowych, włącznie z czasownikami. $\mathrm{Z}$ nielicznymi wyjątkami (np. irstehen, lemmer w indeksie świdnickim) hasła niemie-

${ }^{2}$ Nota bene wydawca słusznie zwrócił uwagę (s. XIII, przyp. 15), że w zapiskach z Jawora tamtejszy podsędek dworski wystąpił o 10-12 lat wcześniej niż w dokumentach. 
cko- i łacińskojęzyczne opatrzono objaśnieniem polskim, niemal zawsze poprawnym i trafnym. Pewne wątpliwości może budzić jedynie przekład ufczuheben jako „rościć” (w odnośnych zapiskach szło raczej o ,niepodważanie” zaprzysięganego miastu pokoju); nieoczywiste jest też tłumaczenie fumatus z zapiski nr 82 księgi świdnickiej jako „spalony” (gdyż mogło tam iść także o przypalanie podejrzanego w celu wydobycia zeznań). Bardzo dobrą praktyką zastosowaną w recenzowanej tu edycji jest umieszczenie w indeksach osobowo-miejscowych odsyłaczy od znormalizowanych bądź utartych w historiografii postaci nazw (np. Bieberstein, Busewoy, Zeiskberg) do rozmaitych występujących w nich wariantów zapisu (w indeksie do księgi świdnickiej znalazło się nawet hasło miejscowe Častolovice, odsyłające do hasła osobowego Potho, dotyczącego Půty II z Častolovic; brak jednak hasła „Czechy”, które odsyłałoby do źródłowej formy Bemen). Odsyłacze do różnych form źródłowych znajdują się także pod nazwami polskimi miejscowości (np. od Cierni do Cirle i Cyrla), nie wiadomo jednak, po co w indeksach odesłania w przeciwną stronę (od form źródłowych do nazw polskich), i to także wtedy, gdy hasła te kierują jedynie z powrotem do jednego i tego samego zapisu ze źródła. Pomijając tę kwestię, trudno mieć jakiekolwiek zarzuty do redakcji i adiustacji indeksów; ewentualne niedopatrzenia dotyczą drugorzędnych w istocie detali (np. występowanie w indeksie jaworskim przymiotników w hasłach łacińskich w przypadkach zależnych zamiast w mianowniku; w indeksie świdnickim hasło gefange zamiast gefangen).

Konstatacja, że z redakcją i adiustacją autor wydania i wydawnictwo poradzili sobie bardzo dobrze, jest zresztą adekwatna nie tylko do poziomu przygotowania indeksów; całe omawiane tu dzieło stoi na wysokim poziomie edytorskim. Jeśli dodać do tego dużą wartość merytoryczną edycji oraz treść i znaczenie samych udostępnianych w niej źródeł, trudno mieć wątpliwości, że omawiana tu książka przyczyni się znacznie do rozwoju badań historycznych i prawnohistorycznych. 